Дзямулич, Наталія. «Дидактичний сенкан як прийом критичного мислення у викладанні курсу „Культура мовлення та виразне читання"». Лінгвостилістичні студії, вип. 10, 2019, с. 45-51.

Dziamulych, Nataliia. "Didactic Cinquain as a Technique of Developing Critical Thinking in Teaching the Course "Culture of Speech and Expressive Reading"'. Linguostylistic Studies, iss. 10, 2019, pp. 45-51.

Удк 373.6(075)

https://doi.org/10.29038/2413-0923-2019-10-45-51

\title{
ДИДАКТИЧНИЙ СЕНКАН ЯК ПРИЙОМ КРИТИЧНОГО МИСЛЕННЯ У ВИКЛАДАННІ КУРСУ «КУЛЬТУРА МОВЛЕННЯ ТА ВИРАЗНЕ ЧИТАННЯ»
}

\author{
Наталія Дзямулич \\ Луцький педагогічний коледж, \\ Луцьк, Україна
}

У статті розкрито поняття «сенкан» та його функціонування в науковометодичній літературі. Вказано основні методологічні вимоги, яким повинна відповідати педагогічна технологія, заснована на використанні критичного мислення. Визначено, що застосування стратегій критичного мислення на заняттях sз культури мовлення дозволяє організувати самостійну діяльність студентів та розвинути їх творчий потенціал. Досліджено сутність поняття «сенкан», його структуру та можливість використання на заняттях з культури мовлення, окреслено способи роботи 3 ним. 3'ясовано, що така форма роботи сприяє оволодінню навичками пізнавальної рефлексії як усвідомлення виконаних дій і розумових процесів, їх результатів і підстав, меж свого знання й незнання, нових пізнавальних завдань і засобів їх досягнення.

Ключові слова: сенкан, критичне мислення, культура мовлення, сучасні педагогічні технології, сучасна вища школа.

Dziamulych Nataliia. Didactic Cinquain as a Technique of Developing Critical Thinking in Teaching the Course "Culture of Speech and Expressive Reading". Thearticle interprets the terms cinquain, modern educational technology, the basic methodological principles of the educational technology based on the usage of critical thinking. High requirements to the professional training of students imply not only knowledge of the professional disciplines but also mastering the culture of speech. The abilities to communicate freely, affirm and convincingly prove that they your opinion are effective means in the formation of critical thinking.

The study has employed fundamental theoretical methods to substantiate the main concepts of the article andto analyzethe methodical, linguistic, psychological and pedagogical literature. Synthesis and generalization of theoretical provisions made it possible to clarify the psychological and linguo-didactical principles of the concept culture of speech. Empirical methods have been applied to reveal the practical use of cinquain and evaluate the results of work with this technique.

One of the most promising among the innovative educational strategies is critical thinking technology because its relevance is predetermined by the socio-cultural needs of modern life and corresponds to the concept of humanization of education. This method is based on the information analysis and enables the students to form their own judgments relying on the available facts and decide whether they are true or false. The study contributes

(C) Дзямулич Н., Східноєвропейський національний університет імені Лесі Українки, 2019.

Це стаття відкритого доступу на умовах CC BY-NC 4.0 
to better understanding of the methods of developing the skills of speech culture and expressive reading of students and arouse interest to creative and non-standard aspects of their professional training. The application of critical thinking strategies at the lessons of speech culture allows to organize an independent activity of the students and develop their creative potential.

The simplified form of the cinquain technique was first launched in the schools of the USA, and in the late $90^{\mathrm{s}}$ of the $20^{\text {th }}$ century it was recommended in the post-Soviet educational process as one of the critical thinking development techniques. Sinquain should be used at all stages of developing culture of speech skills: forming communication competence (a plan for making up monologues and dialogues of various functional types), competence in reading (as a means to control awareness of what you read) and lexical competence (as a way of mastering the vocabulary); competence in writing.

Key words: cinquain, innovation, linguistic culture, modern educational technology, modern high school.

Вступ. Успішна реалізація інноваційних процесів визначається варіативністю та динамічністю змін у підготовці здобувачів освіти та передбачає їхню орієнтацію на творчу діяльність. Високі вимоги до професійної підготовки студентів роблять необхідними не лише знання фахових дисциплін, а й оволодіння культурою мовлення. Адже саме здатність вільно комунікувати, стверджувати та переконливо доводити свою думку $є$ дієвим засобом у формуванні критичного мислення. Культуру мовлення особистості як складову й невід'ємну частину комунікативної культури розглядали Н. Алексєєва, I. Бех, Л. Божович, 3. Калмикова. Зокрема, І.Бех стверджує, що гуманістичне педагогічне спілкування вимагає сформованості відповідних комунікативих умінь і здібностей, якими мають володіти учасники освітнього процесу (38). Основою для нашого дослідження стали праці таких відомих лінгводидактів, як Н. Бабич та М. Пентилюк. Проблемам формування та розвитку критичного мислення студентів присвячено роботи дослідників Т. Воропай, К. Корсак, Т. Олійник, А. Тягло та ін.

Мета дослідження - висвітлення технологій формування критичного мислення студентів на заняттях із культури мовлення, зокрема застосування сенкану як одного з прийомів навчання у вищій школі.

Матеріал і методи дослідження. У підготовці роботи було використано теоретичні методи для уточнення головних понять статті: аналіз методичної, лінгвістичної, психолого-педагогічної літератури. Синтез і узагальнення теоретичних положень уможливив з'ясування психологічних i лінгводидактичних принципів формування культури мовлення. Емпіричні методи застосовано задля спостереження за практичним використанням прийому сенкану та аналізу результатів роботи з цією формою.

Результати дослідження та дискусія. Нові реалії життя вимагають нових підходів та рішень у сфері освіти. Українські заклади вищої освіти, намагаючись відповідати вимогам сьогодення, переживають час змін форм та змісту навчання. Саме тому модернізація освітнього середовища - це 
одне з головних завдань вищої школи. І. Совсун наголошує: «Першочергова місія вищого навчального закладу - давати людям право сміливо висловлюватись, і при цьому - бути відкритим до критики та дискусії. I головне, щоб метою останньої залишався пошук нових знань та ідей. Вільне суспільство не може існувати без можливості дебатувати. А тому йому потрібен простір для обміну інформацією та думками, що і зветься університетом. Саме там зароджується критичне мислення» .

Рушійними силами модернізації освіти $є$ не лише зміни в змісті освітніх дисциплін, а й розширення запасу методичних прийомів та технологій задля активізації діяльності студентів. «Особливого значення на шляху вдосконалення освіти набуває використання як традиційних, так і новітніх освітніх технологій як ефективного способу залучення до культури. Навчальні технології - важливий фактор трансляції культури, оскільки їх ефективне поєднання й застосування дає змогу не лише залучити учнів і студентів до навчальної й наукової діяльності, що значно підвищує ступінь соціалізації особистості, але й опановувати методи, прийоми й знаряддя культуротворення» (Огнев'юк 284). Становлення студента як майбутнього фахівця відбувається в закладі вищої освіти і базується на застосуванні методів та прийомів, результативність яких $\epsilon$ визначальною рівневою характеристикою майбутнього випускника.

На сучасному етапі вища освіта в Україні формується на перетині використання традиційних методів і прийомів та інноваційних технологій навчання. Інновації в навчанні - це поширення нового в педагогічній науці та практиці, «результат творчого пошуку оригінальних, нестандартних рішень різноманітних педагогічних проблем; процес оновлення чи вдосконалення теорії і практики освіти, який оптимізує досягнення ії мети» (Інноваційні технології 6).

Однією 3 найперспективніших серед інноваційних технологій $€$ технологія критичного мислення, адже іiі актуальність зумовлена соціокультурними потребами сучасного життя і відповідає концепції гуманізації освіти. Цей метод базується на аналізі інформації й дозволяє будувати власні судження, спираючись на всі наявні факти та здатність їх оцінювати як істинні чи хибні. Девід Клустер зауважив: «Критичне мислення $є$ мислення самостійне. Коли заняття будується на принципах критичного мислення, кожен формулює свої ідеї, оцінки і переконання незалежно від інших» (24).

Навички критичного мислення дають такі можливості:

- розуміти логічні зв'язки між ідеями;

- виявляти, конструювати та оцінювати аргументи;

- виявляти невідповідності та поширені помилки в міркуваннях;

- системно вирішувати проблеми;

- визначити актуальність та важливість ідей;

- обгрунтовувати власні переконання та цінності. 
Помилковою $є$ думка про те, що критичне мислення перешкоджає творчості, оскільки вимагає дотримання правил логіки та раціональності, а творчість може спричиняти порушення правил. Критичне мислення цілком сумісне з нестандартним мисленням і $\epsilon$ своєрідним викликом банальності та шаблонам. Технології критичного мислення $є$ невід'ємною частиною творчості, адже воно потрібне для того, щоб оцінити i вдосконалити творчі ідеї.

Критичне мислення підвищує мовні та презентаційні навички, адже точність і систематичність думки вдосконалюють спосіб висловлення наших ідей, покращує розуміння логічної структури. Творче вирішення проблеми передбачає не тільки наявність нових ідей, необхідно також, щоб нові ідеї, що генеруються, були корисними та актуальними. Саме під час розв'язання творчих завдань критичне мислення відіграє вирішальну роль в оцінці нових ідей, виборі найкращих і зміні їх, якщо це необхідно.

Безперечною $\epsilon$ актуальність проблеми формування умінь і навичок культури мовлення та виразного читання в студентів. Саме це зумовлює підвищення уваги до творчих, нестандартних аспектів їхньої фахової підготовки. Застосування на заняттях 3 культури мовлення стратегій критичного мислення дозволяє організувати самостійну діяльність студентів та розвинути їх творчий потенціал. Якість формування мовленнєвої культури залежить не тільки від використання певної кількості наукової інформації, але й від творчої діяльності студента та можливостей її засвоєння, емоцій викладача, його вміння систематично включати студентів у роботу, засвоювати мовленнєві знання і вміння не тільки на заняттях, але й у процесі самостійної праці. Для підвищення рівня культури мовлення майбутніх педагогів слід активізувати творчу діяльність студентів.

Спрощена дидактична форма сенкана сформувалась у шкільній практиці США, а наприкінці 90-х років XX століття з'явилась і на пострадянському освітньому просторі як один з прийомів критичного мислення на етапі рефлексії.

Дидактичний сенкан укладають не за вимогами структури (на відміну від поетичної форми), а згідно зі змістовими й синтаксичними вимогами до кожного рядка. Сенкан (синквейн) дозволяє в декількох словах викласти навчальний матеріал на певну тему. Це вірш, що складається з 5 рядків, одинадцяти слів та вимагає синтезу інформації й матеріалу в коротких висловах. Його створюють за вже добре відомою схемою. Перший рядок - тема, один іменник або займенник, який позначає об'єкт обговорення. Другий рядок - два прикметники або дієприкметники, що описують і характеризують тему. Третій - три дієслова про характерні дії об’єкта. У четвертому рядку маємо цілу фразу з чотирьох слів, за допомогою якої висловлюємо особисте враження, розуміння теми (інколи вдалим $\epsilon$ використання цитати з тексту, прислів'я). П'ятий рядок - це одне 
слово-резюме (зазвичай іменник), синонім до теми, що $є$ підсумком i висловлює сутність об'єкта (Дзямулич 65).

Складаючи сенкан, студент може звертатися до тексту за досліджуваною темою. При цьому порядковість завдань $\epsilon$ своєрідною схемою, орієнтовною основою для роботи, за допомогою якої виконують конкретний фрагмент завдання для складання сенкану. Використовуючи цей прийом, ми даємо змогу студентам реалізувати свої особистісні здібності: інтелектуальні, творчі тощо.

Уміння складати сенкан за тією чи тією темою свідчить про ступінь володіння матеріалом, зокрема $є$ показником того, що студент: знає зміст навчального матеріалу теми; вміє виділяти найбільш характерні особливості досліджуваного процесу чи явища; вміє застосовувати отримані знання для розв'язання нового для нього завдання.

Традиційно визначають такі організаційні форми роботи з сенканом: 1) самостійно при підготовці до занять; 2) самостійно на практичних заняттях; 3) у складі малої групи; 4) для визначення найкращого сенкана, складеного за обраною темою; 5) у складі навчальної групи за участю викладача, який допомагає групі скласти сенкан; 6) при виконанні контрольного завдання на складання сенкана, написання розповіді за сенканом або визначення теми неповного сенкана; 7) робота в парі над сенканом за однією темою.

Різні варіації для складання сенкану сприяють різноплановому складанню завдань. Викладачі-практики пропонують різноманітні способи роботи 3 сенканом: складання нового сенкану; складання короткої розповіді за готовим сенканом із використанням слів і фраз, які входять до його складу; сенкан-загадка; аналіз неповного сенкана без вказівки теми і визначення його теми; корекція і вдосконалення сенкана.

При формуванні комунікативних умінь особливу роль відіграє складання дидактичного сенкана без називання теми та аналіз неповного сенкана для визначення відсутньої частини. Це дає такі переваги: можливість одночасно залучати велику кількість студентів; швидкість виконання завдань; здійснення індивідуального підходу через варіативність завдань (тем).

Аналіз неповного сенкана для визначення відсутньої частини призначений в основному для повторювання, закріплення матеріалу за темою. Він вимагає від студентів простого відтворення відомих досліджуваних фактів та понять. Наприклад:

$$
\text { —_._.(Пауза) }
$$

Коротка, логічна.

Зупиняє, триває, розділяє.

Важливий складовий елемент засобів логіко-емоційної виразності читання.

Зупинка.

Або: 
_._.(Логічність мовлення)

Розумно, аргументовано.

Думати, впорядковувати, аналізувати.

Покращує розуміння висловленого мовцем.

Консеквентно.

Зрозуміло, що такі завдання водночас створюють певні умови для переходу до виконання інших завдань, які вимагають більш високого рівня пізнавальної активності і самостійності.

Наведемо також приклади практичних завдань-сенканів, створених студентами на заняттях із культури мовлення:

Риторика.

Антична, сучасна.

Розмовляти, переконувати, вражати.

Перемогти етосом, пафосом, логосом.

Красномовство.

Або:

Акція.

Завершальна, найяскравіша.

Промовляти, виступати, доводити.

Фінальний етап - реалізація задуму.

Buступ.

Серед переваг роботи з цією формою $є$ й те, що правильно складений сенкан має яскраво виражене емоційне забарвлення, розвиває мовлення, вчить аналізувати навчальний матеріал, критично мислити, визначати найважливіше, робити висновки й коротко їх формулювати. Крім того, це дає можливість авторові відчути себе успішним, талановитим, уміти висловлювати свою думку і відстоювати їі.

Отже, сенкан доцільно використовувати на всіх етапах навчання культури мовлення:

- при формуванні комунікаційної компетентності - як плану для укладання монологів та діалогів різних функціональних типів;

- компетентності в читанні - як способу контролю усвідомлення прочитаного;

- лексичної компетентності - як способу оцінки словникового запасу студентів;

- компетентності в писемному мовленні - як схеми для написання твору тощо.

Можемо вважати, що процедура складання сенкана дозволяє гармонійно поєднувати елементи всіх трьох головних освітніх систем: інформаційної, діяльнісної та особистісно орієнтованої.

Висновки та перспективи досліджень. Отже, сенкан як один із прийомів розвитку критичного мислення сприяє формуванню вміння самостійно визначати мету діяльності та складати плани діяльності; самостійно здійснювати, контролювати й коригувати діяльність; 
використовувати всі можливі ресурси для досягнення поставленої мети і реалізації планів діяльності; вибирати успішні стратегії в різних ситуаціях. Така форма роботи на заняттях з культури мовлення сприяє оволодінню навичками пізнавальної рефлексії як усвідомлення виконаних дій i розумових процесів, їх результатів і підстав, меж свого знання й незнання, нових пізнавальних завдань і засобів їх досягнення. Він удосконалює навички пізнавальної та проектної діяльності, навички вирішення проблем; здатність і готовність до самостійного пошуку методів виконаних практичних завдань, застосування різних методів пізнання. Сенкан налаштовує на самостійну інформаційно-пізнавальну діяльність, включаючи вміння орієнтуватися в різних джерелах інформації, критично оцінювати та пояснювати дані, одержані з різних джерел.

\section{Список використаної літератури}

Бех, Іван. «Особистість: два наукових погляди на виховання та розвиток». Психологія $i$ особистість, № 2, 2013, с. 132-140.

Дзямулич, Наталія. «Сенкан у системі інноваційного навчання». Педагогічний пошук, № 4, 2010, с. 64-6.

Інноваційні технології навчання української мови і літератури. Тернопіль: Астон, 2005.

Клустер, Дэвид. «Что такое критическое мышление?» Критическое мышление и новые виды грамотности. Москва: ЦГЛ, 2005, с. 5-13.

Культура фахового мовлення, за ред. Н. Д. Бабич. Чернівці: Книги-XXI, 2006.

Огнев'юк, Віктор. Освіта в системі цінностей сталого людського розвитку. Київ: Знання України, 2003.

Пентилюк, Марія. Культура мови і стилістика. Київ: Вежа, 1994.

Совсун, Інна. Реформа вищої освіти - це не вторинне «соціальне» чи «гуманітарне» питання, а ключовий політичний виклик для Украӥни. URL: https://nv.ua/ukr/opinion/universitet-vilnikh-ljudej-2469362.html

\section{References}

Bekh Ivan. "Personality: Two Scientific Views on Upbringing and Development". Psychology and Personality, no 2, 2013, pp. 132-140.

Dziamulych, Nataliia. "Senkan u systemi innovatsiinoho navchannia". Pedahohichnyi poshuk, no 4, 2010, pp. 64-6.

Innovatsiini tekhnolohii navchannia ukrainskoi movy i literatury. Ternopil: Aston, 2005.

Kluster, Djevid. "Chto takoe kriticheskoe myshlenie?" Kriticheskoe myshlenie $i$ novye vidy gramotnosti. Moskva: CGL, 2005, pp. 5-13.

Kultura fakhovoho movlennia, edited by N. D. Babych. Chernivtsi: Knyhy-XXI, 2006.

Ohneviuk, Viktor. Osvita v systemi tsinnostei staloho liudskoho rozvytku. Kyiv: Znannia Ukrainy, 2003.

Pentyliuk, Mariia. Kultura movy i stylistyka. Kyiv: Vezha, 1994.

Sovsun, Inna. Reforma vyshchoi osvity - tse ne vtorynne "sotsialne" chy "humanitarne" pytannia, a kliuchovyi politychnyi vyklyk dlia Ukrainy. nv.ua/ukr/opinion/ universitet-vilnikh-ljudej-2469362.html 